\title{
A Secret Society Goes Public: The Relationship Between Abakuá and Cuban Popular Culture
}

\author{
Ivor Miller
}

\begin{abstract}
The Abakuá Society for men is derived from the West African Ékpè Societies of the Cross River region. It was founded in Havana, Cuba, in 1836 to resist slavery, and has since been active in many aspects of Cuban culture. Although hermetic and little known even within Cuba, an analysis of Cuban popular music recorded from the 1920 s until the present reveals Abakuá influence in nearly every genre of Cuban popular music. Abakuá lore is orally transmitted, and Cuban musicians who are Abakuá members have continually documented key aspects of their society's history in commercial recordings, often in Abakuá language. Because theirs is a secret language for initiates only, Abakuá have commercially recorded actual chants of the society, knowing that outsiders cannot interpret them. Even so, these recordings have been very popular because the Abakuá represent a rebellious, even anticolonial, aspect of Cuban culture. Now played throughout the Americas, Africa, Europe, and Asia, Guban popular music and its derivatives maintain Abakuá language and aesthetics as integral elements. Because so little has been written about the society by members themselves, commercial recordings with Abakuá content are an important source of knowledge about this group. While listening to the lyrics, I realized that Abakuá musicians have sung about their contributions to Guban history, their liberation struggles, and race relations. My research suggests the rising importance of Abakuá as a symbol of Cuban culture.
\end{abstract}

Résumé: La Société des hommes Abakuá tire son origine des Sociétés Ékpè ouest africaines de la région de Cross River. Elle fut fondéc à Havane à Cuba en 1836 pour résister à l'esclavage et est depuis active dans bien des aspects de la culture cubaine. Bien qu'elle reste hermétique et peu connue même à l'intérieur de Cuba, une analyse de la musique populaire cubaine enregistrée depuis les années 1920

African Studies Review, Volume 43, Number 1 (April 2000), pp. 161-88

Ivor Miller is a scholar-in-residence at the Schomburg Center for Research in Black Culture, 1999-2000. He is also a translator at the Editorial José Martí in Havana. Research for this article was funded by the National Endowment for the Humanities through the Schomburg Center for Research in Black Culture's scholar-inresidence program. 


\section{African Studies Review}

jusqu'à nos jours révèle l'influence Abakuá dans presque tous les genres de musique populaire cubaine. La tradition Abakuá est transmise oralement, et les musiciens cubains membres d'Abakuá ont continuellement documenté des aspects essentiels de l'histoire de leur société dans des enregistrements commerciaux, souvent en langue Abakuá. Comme leur langue est une langue secrète réservée exclusivement aux initiés, les Abakuá ont enregistré dans le commerce de véritables chants de cette société, tout en sachant que les profanes ne pourraient pas les interpréter. Pourtant, ces enregistrements furent extrêmement populaires car les Abakuá représentent un aspect rebelle, voire anticolonialiste de la culture cubaine. Aujourd'hui jouée partout dans les Amériques, en Afrique, en Europe et en Asie, la musique populaire cubaine et ses dérivés maintiennent la langue et l'esthétique Abakuá comme parties intégrantes. Parce que si peu a été écrit sur cette société par ses membres eux-mêmes, les enregistrements commerciaux comprenant un contenu Abakuá sont une source importante de connaissances sur ce groupe. En écoutant leurs paroles, nous nous sommes rendus compte que les musiciens Abakuá ont chanté leurs contributions à l'histoire cubaine, leurs luttes pour la libération et les relations entre les races. Nos recherches suggèrent l'importance grandissante d'Abakuá en tant que symbole de la culture cubaine.

La amistad a un lado y el Abakuá separado.

(Friendship is one thing, and the Abakuá another.)

—Abakuá saying

A great obstacle to our understanding of the cultural dimensions of the African diaspora in the Americas is the paucity of written documentation left by those who were sold and transported as slaves, that is, by those who experienced the worst forms of oppression. Scholars have stressed the importance of examining the history of those workers who resisted the slave system. Antonio Benítez-Rojo writes: "The Caribbean's 'other' history...starting from the palenque and the maroon... builds an enormous branching narration that will serve as an alternative to the 'planters' histories' that we know" (1992:254). But where are the histories of those who left no written trace? Often they live in the memories of their descendants. Many legends, epics, and forms of esoteric knowledge (divination, rites of passage) derived from West African societies are maintained in Caribbean cultures in the form of oral literature, song, and chant. By recording oral history with elders as one means of understanding the recent past, Bascom (1980), Cabrera (1988), Warner-Lewis (1996) and others have helped document this rich legacy, indispensable for understanding the popular culture of many Caribbean nations. 
In my own field research in Cuba, I have documented the linguistic impact of West Africa in Cuba, as well as the religious customs, social organization, and visual symbolism that go with it. To do this I have relied heavily on audio recorded interviews with elder practitioners of Afro-Cuban religions. After working for several years with these elders, with Cuban musicians who helped create twentieth-century popular music, and with West African language specialists and speakers, I conclude that the African linguistic heritage on this side of the Atlantic is today strong enough to support a general theory for the regeneration of African religion and artistic culture in the Americas. I have also found that early recordings of Cuban music offer another important avenue into the culture and perspectives of Cubans of African descent.

Popular music around the globe is created by working-class people to describe and celebrate their experiences. In the Caribbean, popular music has a special significance for students of the African diaspora because the descendants of Africans have recorded hundreds of references to the oral literature of their ancestors, using them to describe their reality. These musical texts-recorded and then distributed internationally (in fact often recorded outside of the home country) — can be vital sources for mapping some of the linguistic and historic dimensions of the diaspora.

The study of Abakuá has the same problems as the study of other secret societies with bodies of esoteric knowledge. As with Cuban Santería, a key source of information is the testimony of knowledgeable elders. Abakua is unique in the African diaspora, however, because throughout this century, members of the society have recorded ceremonial chants, origin myths, and historical events in their liturgical language, and these have entered the mainstream of Cuban popular culture.

Another facet to the issue of Afro-Cuban religion and Cuban society is the emergence of the Abakuá as a national symbol. This was a prominent theme among artists and intellectuals in the Afrocubanismo movement of the 1920s and thirties. During the 1959 Cuban Revolution, the anticolonial liberation struggles of black Cubans were framed (albeit inconsistently) as important precedents to the current regime. In this light, the historically rebellious stance of the Abakua against Spanish colonists has allowed them again to be presented as a symbol of national culture. In the economic crisis since 1990, the appeal of Afro-Cuban culture to tourists has resulted in many recent booklets and commercial recordings related to the society. While these products have raised awareness of the society's existence, they do not, unfortunately, benefit the brotherhood monetarily.

\section{The Abakuá Society}

The Abakuá society is one of the least known yet most powerful examples of West African cultural influence in the Americas. A mutual aid society for 
men based on religion, it was established by Africans in Regla, Havana, in 1836. Abakua is derived principally from the male "leopard societies" of the Àbàkpà (Ejagham), Efut, and Ėfik peoples of the Cross River basin (Old

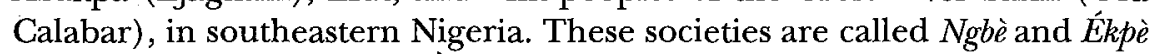
after the Ejagham and Ėfik terms for "leopard" (Talbot 1912:38; Williamson \& Shimizu 1968:222-23). As Africans arrived in Cuba during the time of the slave trade, the Spanish government divided them ethnically by encouraging those in urban areas to form cabildos, or "nation" groups in urban centers like Havana, Matanzas, Santiago, and Cienfuegos. Cabildos became important centers for the conservation of African languages and cultural practices. Cross River peoples formed several cabildos in the eighteenth century, and titled members of the "leopard societies" were among them. ${ }^{1}$

The oral histories that I collected from Abakuá elders and their families (during fieldwork conducted in Cuba between 1991 and 1999) have confirmed that the Cuban-born descendants of Africans (called Creoles) were not permitted to enter the Calabari secret society as it existed among Africans. The Abakuá society was established as a Cuban institution in 1836 when the Calabari cabildo Ápapa Efí sponsored the founding of a group comprising Cuban-born blacks, naming it Efí Kebúton. Since then this non-proselytizing, non-text based institution has expanded to the port cities of Havana, Matanzas, and Cárdenas in northwestern Cuba. Earlier scholars documented how the Abakuá society became self-organized to buy slaves their freedom, and that its members participated in the independence movements against Spanish authorities. ${ }^{2}$ As an organized work force, Abakuá were highly influential in the wharves of Havana for over one hundred years (Deschamps 1971:93). Each group, initially composed of approximately twenty-five men, could grow to be several hundred strong. In 1882, Trujillo documented eighty-three Abakuá groups in Havana (1882:372). In 1914 Carpentier documented fifty-seven Abakuá groups in Cuba (a number that is probably low) (1980:291). Now there are approximately 117 groups functioning, with an estimated total of twenty thousand members. ${ }^{3}$

The phrase "Friendship is one thing, and the Abakuá another" underlies one reason the Cuban Abakuá have remained hermetic for over 160 years: the oaths of loyalty to the society's sacred objects, members, and esoteric knowledge taken by initiates are a lifelong pact, creating a sacred kinship arguably as important as the family. One's duties to a friend are great, but the duties of an Abakuá member to his ritual brothers at times surpass even the responsibilities of friendship. One of the oaths made during initiation is that one will not reveal the "secrets" of the Abakuá to non-initiates. ${ }^{4}$ Although the boundaries of what constitutes a secret are often disputed among elders, many consider all information intimate, and not even their families know of their membership. Others consider only the rituals that take place in the sacred famba room as secret, and encourage the study of 
the society's history. One of the ramifications of this dispute is a lack of welldocumented histories of the Abakuá and their impact in Cuban history.

Abakuá groups are probably similar in structure to Masonic lodges. ${ }^{5}$ Abakuá members call their groups juegos, partidos, potencias, or tierras. Juego, the word most commonly used, refers to a team or an aligned collective. Partido refers to a team or a political party. Potencia, meaning "potency" or "power," is reserved for the eldest and largest groups, some of which are almost 160 years old and include six hundred men. Their power lies not only in the number of members, but also in the age of their sacred attributes, some of them made by the Calabari founders of Abakuá. Tierra, another word used to describe Abakuá groups, literally means "land," yet it is used expansively to include the ideas of territory, nation, or land of the ancestors, meaning the three regions of Calabar that gave roots to the Abakuá, known in Cuba as Efí (Ėfik), Efó (Efut), and Orú (Oron). Abakuá juegos are founded and named based on tratados (origin myths or mythic histories) from Old Calabar, each recounting how various territories joined the sacred brotherhood. Thus each group is mythically descendant from Efi, Efo, or Orú. In ceremonies the actions of important ancestors from these territories are enacted, recited, and sung about.

Juegos are composed of a hierarchy of dignitaries. Each post or position-called in Spanish plaza and in Abakuá obón (obong means "king" in Ėfik)-is charged with specific responsibilities. The various Abakuá obónes required to conduct ceremonies, each one with a distinct and vital function, reflect the social organization of the Cross River region before British rule in Nigeria. Several of the highest dignitaries receive a scepter called a muñon - each muñón representing a founding ancestor of the society (Ortiz 1955:241). The muñones and sacred drums, emblems, and signs are metonyms for mythic and actual people, animals, and symbols important in Abakuá history.

The term for ceremony-plantar (literally "to plant") - is intimately connected to ideas of land and of founding. The term plantar associates ritual actions with the planting of trees sacred to Abakuá. Abstract ideas like God, brotherhood, unity, and ancestors are concretized in Abakuá practice through metaphoric associations with the land.

At the core of Abakua tradition is the fundamento ${ }^{6}$ Its multiple meanings, felt in all aspects of the society, imply sacred law and moral authority. Elders who transmit sacred knowledge are considered fundamento. Objects in which supernatural forces are concentrated are called fundamentos. Ultimately the fundamentos represent the supreme divinity (Abasí), the source of all existence. Abakuá origin myths tell that this force was embodied by Tánse, the divine fish whose capture led to the creation of the society in Africa. The fundamento central to all ritual action is the Bongó Ékue, which in turn represents Tánse; it is the sacred drum through which the Voice of God reverberates. ${ }^{7}$ Other ceremonial objects such as drums, scepters, masquerade costumes, and cauldrons contain and often can transmit funda- 
mento after ritualized contact with the Ékue drum. Many fundamentos are constructed using materials taken from the earth, where ancestors are buried, and from the bush, where sacred medicines grow. The society functions like an extended family, with diverse ancestors, but the fundamento is regarded as the original ancestor, now divine. The sacred oaths made during initiation to the fundamento must not be transgressed. Doing so, it is believed, puts one in grave danger.

Because Abakuá fundamentos are established in northwestern Cuba, this region is the center of all the society's activity. The consecration of land that accompanied the creation of the first fundamento by Calabari immigrants definitively established Abakuá in Cuban soil. This act was a vital strand in the continual construction of Cuba as sacred land. Cuban Abakuá do not look upon the geographical location of Africa as homeland, as did the original Rastafarians of Jamaica who sought repatriation to "Ethiopia." On the contrary, Abakuá fundamentos allow the society to exist as a separate state within the nation, with their own language and laws. Because they live on ground consecrated by their fundamentos, Abakuá groups consider themselves sovereign lands (tierras) whose primary allegiance is to Ékue, the fundamento. ${ }^{9}$

Although its leaders consider their groups sovereign lands, all Abakuá groups share a common mythology and organizing structure. Following the tratado of each group, they are identified with one of the several Cross River ethnic groups-Efí, Efó, and Orú. These groups are relatively independent yet are answerable to a group of elders (recognized for their mastery of Abakuá lore) who convene in times of crisis. For example, in the mid-twentieth century, a basaibeke (knowledgeable elder) like "Chuchú" Capáz of Regla, Havana, and his disciples recreated and reorganized several groups whose aging members had died. In 1998 I witnessed a multijuego collective of obónes conduct an initiation ceremony to fill in vacancies in the groups' knowledgeable membership. ${ }^{10}$ In this way, the independent groups act as a society, respecting the uniqueness of each group (considered a tribe by its members), and acting collectively in crisis moments.

\section{The Abakuá Language}

A variety of distinct ethnic groups inhabiting southeastern Nigeria and western Cameroon were exported to the Caribbean region as slaves. Because, on the one hand, the port from which many departed was Old Calabar, and on the other, the language of many others (from the Niger delta) was Kalabari, many of them became known as "Calabari" (and later in Cuba, "Carabalí," reversing the $l$ and $r$ ), the same way that various Yorùbá subgroups became known collectively as the "Lukumí," and various Bantu groups became known as the "Congo." One way to understand the trans- 
formation of many distinct but culturally related peoples into the Cuban Carabalí is to examine the diverse sources for their language. ${ }^{11}$

Languages created by African slaves, like Louisiana Creole or Haitian, commonly utilize the vocabularies of European languages and make use of their own indigenous grammar (Arends et al.1994:10, 99; Hall 1992: 188). Now termed "creole languages," they were used by newly transported Africans of diverse regions to communicate with each other as well as with whites. In contrast, as Abakuá was not used to communicate with non-Cross River people in contact situations, it is not a creole language at all. The influence of Spanish appears to be minimal, found primarily in the plurals at the end of words. As an esoteric language used exclusively for ceremonial purposes among initiated men, it is more likely a mixture of various "initiation dialects" (called "argots" by some scholars) of the Cross River region. This possibility must be considered seriously because many West African guilds have such initiation languages unknown to non-initiates, such as the enà (initiation language) of the bàtá and the dùndún drummers guild (called Àyàn) of the Ọyọ́ Yorùbá (Abímbọ́lá 1998). Among the İgbo, members of the Âyáka society learn "secret or fancy words" (Meek 1937:73). The titled elders in the İgbo kingdom of Ǹri used a "secret language" called ólú to communicate amongst themselves in order to maintain "ritual/economic monopoly" (Manfredi 1991:265-73).

Many key words in the Abakuá language are slightly transformed from words still used in the Calabar region (Sosa 1982:395-414); for example, the word ireme (spirit dancer) derives from the Éfik idem; Ekue (sacred drum) derives from the Èfik ékpè (leopard); asére (ritual greetings) derives from the Ejagham (Ekoi) asere. Used to evoke ancestral forces and the Great Power of God, Abakuá words are believed to motivate inanimate forces into action. We cannot be more conclusive as to the linguistic history and structure of Abakuá variants until collaborative research between Guban Abakuá and Nigerian Ékpè language speakers is conducted. The Abakuá source texts-the epic narrative of the society's creation-are maintained in the orally transmitted Abakuá language. In contemporary Cuba, there are two Abakuá linguistic varieties: Brikamo Kalabari (used to conduct ceremonies throughout the society) and Suáma (of İgbo derivation and spoken only in Matanzas). This results in considerable variations in stock Abakuá phrases, and each master has a unique way of understanding and relating them.

The performance of Abakuá language is a key element to leadership in the society. Members constantly test each others' knowledge by discoursing in Abakuá, following one phrase with another which the next person must respond to and then take the discussion further, until a gap is left which the less knowledgeable person cannot fill. Dialectic interaction is core to Abakuá performance, whether in call-and-response recitations or in polymetric interactions among the Íreme dancers, drummers, and dignitaries.

The Abakuá language has influenced Cuban popular speech, as in the 
word chébere (or chévere) which is used popularly to mean "valiant, wonderful, excellent" after "Ma' chébere,". a title of the Abakuá dignitary Mokóngo. (A diviner and royal counselor of Old Calabar, Mokóngo was considered valiant because he swore himself into the society by maneuvering intelligently through opposing factions.) And what young man familiar with the Havana streets does not know the words asére, ekóbio, or monina, all Abakuá terms for "ritual brother," which are used in a standard hepster greeting? (Asére is a ritual form of salutation; ekóbio is a ritual brother; moni$n a$ is a ritual or "soul" brother [Cabrera 1988:71-76,162,354]). Abakuáinspired street lingo has even been recorded in popular music, as in the song "Los Sitio' Asere" (Salutation to Los Sitios), whose title refers to a Havana barrio with several Abakuá groups (Afro-Cuban All Stars 1997). In addition, Abakuá sayings and moral codes have been translated into Spanish. For example, "Mútián keréké wasán korókó iruá/ Oreja no puede pasar cabeza" (The ear cannot surpass the head) means, in effect, that youth cannot surpass the knowledge of an elder. ${ }^{12}$

\section{Afrocubanismo and the Abakuá: A Quintessential Symbol of the Nation}

Abakuá ceremonial performance must have style, flash, dexterity, and conviction. The rich and complex rites of the society include performance of highly symbolic movement, rhythm, song, and the drawing of ideograms, much of which has in turn inspired artists and intellectuals who are not members of the society. In the nineteenth century, Víctor Patricio de Landaluze (1828-89, Spanish) created a series of images depicting Abakuá Íreme in Havana that have become icons for Afro-Cuban culture. When the contradance of England and France was brought to Cuba by planters escaping the Haitian Revolution in the early 1800 s, the titles given by Cuban composers to some of their contradanzas referred to the Abakuá, such as in the compositions "La fambá" and "Los ñáñigos" (Lapique 1979:40-42). These are some of the first signs of the Abakuá emerging as a national symbol.

Although Bantu/Kongo and Lukumí influences are tremendous in Cuba, only the Abakuá are endemic to Cuba. That they are also anticolonial, highly organized, exclusively male, secret, and uniquely costumed made the Abakuá a key symbol for the Afrocubanistas, a group of intellectuals in the early twentieth century who sought to define a national culture. Partially inspired by the Harlem Renaissance and "Bohemian" Paris of the 1920s and thirties, the artistic movement that emerged in Havana called Afrocubanismo also drew inspiration from local black and mulatto working-class cultures, although many of its works were created by outsiders to Afro-Cuban religious traditions (Moore 1997:275). At the forefront of this movement were Fernando Ortiz, who in 1923 founded the Sociedad de 
Folklore Cubano; Nicolas Guillén, who published his first book of poetry, Motivos de son, in 1930; Alejo Carpentier, who published his first book, ¡Ecue-Yamba-O!, based on the Abakuá, in 1933; and Lydia Cabrera, who published Contes Nègres de Cuba (Paris, 1936). ${ }^{13}$ Cuba's renowned composer Ernesto Lecuona frequently used Afro-Cuban themes in his salon music, such as his 1930 "Danza de los ñáñigos." In 1928 both Rita Montaner (Spottswood 1990:2123-24) and Ronda Lirica Oriental (Caignet 1993) recorded "Carabalî" by Félix Caignet (1892-1976), a composition inspired by the cabildo Carabali Isuama in Santiago de Cuba. Important for its celebration of the integration of African culture into Cuban society, "Carabalî" was also performed by Rita Montaner in Paris in the late 1920s (Moore 1997:174; Caignet 1993).

Just as both Antonín Dvořák and Béla Bartók used eastern European folk music in their compositions, Cuban symphonic composers Amadeo Roldán (1900-1939) and Alejandro García Caturla (1906-40) used AfroCuban themes in their own works, which became symbolic expressions of Cuban nationalism. Roldán worked with an Abakuá drummer and had his own Abakuá drums constructed. The compositions "La rebambaramba" (1928), "Rítmicas" (1930), and "El diablito baila" by Roldán, and "Berceuse campesina" and "Yamba-O" (1928-29) by Caturla use themes and structures of Abakuá and other Afro-Cuban music (León 1991:280-81; Carpentier 1980:305-29; Moore 1997:205-6). ${ }^{14}$ "Poemas Afrocubanos," a collaborative effort between Caturla and Carpentier using Abakuá themes, was premiered in Paris in 1929 (Caturla 1980).

In the visual arts, Cuba's most famous painter, Wifredo Lam, was inspired by Afro-Cuban religions. Returning from an apprenticeship with Picasso in France, Lam lived in Cuba from 1941 to 1952, where Alejo Carpentier and Lydia Cabrera encouraged his exploration of Afro-Cuban themes. A 1943 painting (untitled) depicts an Abakuá Íreme with conical headgear and playing a drum. The conical Abakuá mask appears repeatedly in Lam's later work in abstracted forms. In 1947 he painted "Cuarto Fambá," his imaginary recreation of the Abakuá initiation room, which of course he never saw (Wifredo Lam, 1992).

Abakuá ceremonies are based on performances of liturgical drumming, dancing, and chanting. Outside of the actual ceremonies of the society, Abakuá musicians have dramatically influenced Cuban popular music. Since the colonial days, the majority of all Cuban musicians have been Africans and their descendants (Moore 1997:19) ${ }^{15}$ Abakuá musicians in particular, being familiar with polyrhythmic drumming traditions central to Afro-Cuban religions, integrated these rhythms-as well as other verbal and musical elements from Afro-Cuban religions-into popular music as it emerged in the late nineteenth and early twentieth centuries.

Elder musicians in Havana like "Juanillo" Febles (1914-) remember that composer Enrique Peña (1881-1924), a cornet player in the Independence (Mambi) army of general Antonio Maceo, was an Abakuá member 
(Febles 1996). ${ }^{16}$ His 1921 composition "El Ñanigo" pays homage to the role of Abakuá in the Wars of Independence. Febles, who performed "E1 Náñigo," describes this danza (a variant of the European contradanza) as beginning with the tune of a military call to arms (llamada a combate), which segues into an elegant dance tune. ${ }^{17}$ Through this composition, Peña implies that Abakuá are warriors for independence and move with elegance and strength. The danza is distinctive in Cuban popular music for its use of a $6 / 8$ rhythm in the melody section, the standard meter for Abakuá ceremonial music. In this danza, Peña uses a $6 / 8$ rhythm and a melody from an Abakuá chant.

Miguel Failde (1852-1921) is credited with creating another related genre, the danzón, in 1879. Scholars suspect that he was an Abakuá member. ${ }^{18}$ The titles of danzones by other composers using Abakuá terms such as "Chevere Macumchevere" (Serviá n.d.), "Ireme maco Ireme," and "Ireme" name their inspiration. ${ }^{19}$ The composer and director Obdulio Morales (1910-) similarly incorporated many Afro-Cuban elements into his music. In the 1940s he presented conferences on Afro-Cuban music at the Sociedad de Estudios Afrocubanos (founded by Fernando Ortiz in 1936). His compositions "Ecué" (recorded in the 1950s), "Enyoró" (a term for an Abakuá funerary rite, recorded in 1937), and "La Culebra" (the snake) have obvious references to Abakuá practices. In "La Culebra," Morales plays with this most potent symbol of Abakuá (as well as Kongo) traditions. The snake symbolizes the mystic powers of the dignitary Nasakó to motivate forces in the natural world on behalf of his group. The chorus for "La Culebra" is strikingly similar to an Abakuá chant used by the dignitary Enkríkamo when calling out an Íreme to dance in ceremony. Morales wrote, "Ven, pa'ca, cuidado con la culebra que muerde los pies" (Come here, watch out for the snake that bites the feet). As one elder recited it to me, the ceremonial chant is "Ireme, be careful, watch your feet because a snake might entangle you" (Miller forthcoming).

When Beny More (1919-1963) sang, "In the colonial days, the days of the Sese eribó," he referred to one of the Abakuá fundamentos, the divine Sese eribó drum used to initiate new members. ${ }^{20}$ In this song, Moré uses his art form to re-map Cuban history from the perspective of free and enslaved blacks, glorifying the Calabari culture re-created in Cuba to organize and defend them. In a later version, Carlos Embale (1923-99) proclaims, "Kiñongo, kiñongo" (meaning "a person sworn in" or "an Abakuá member") (Embale 1995). ${ }^{21}$ In 1936, Arsenio Rodríguez (1911-71) sang, "I am Carabali, a black African, ... without liberty I cannot live." ${ }^{22}$ Although not Abakuá, but from a Kongo family lineage, Rodríguez refers to the Calabari, legendary for their rebelliousness, to voice the desire of all black Cubans for self-determination. ${ }^{23}$

By the 1850 s, Abakuá was clearly an anti-Spanish colonial and "indigenous" force on the island. In the context of Spanish repression, the mutual aid rendered by the society made it attractive to Cuban males of any eth- 
nicity. In turn, some Abakuá elders realized that an inclusive membership policy would help the society survive. White Cubans became Abakuá members from 1857 onward: Enyegueyé Efó was founded as a group of white Abakuá in the late nineteenth century. The 1928 recording of "Criolla Carabali" by the (black and mulatto) Sexteto Habanero refers to the process of creolization, or cubanizing, of the Calabari society as it accepted first non-Calabarí, and later non-black, members. The "criolla" nature of the society made it entirely Cuban. The continual integration of the society by mulattos, Chinese, and whites meant that it reflected the diversity of Cuban society much earlier than any governmental institution.

"Criolla Carabali" contains Abakuá rhythms and phrases performed in the public segments of the society's ceremonies (Sexteto Habanero 1995a). Gerardo Martínez, lead vocal in this recording and an Abakuá member, chants, "Heyey bario bakongo Sése Eribo eróko embóko baróko nansáo, abairémo Efi, abairémo Efó, bongó Ita, Sése akanarán biankomo komo iremo Abasí ama Abasí manyobino" (Attention to all, the Sése Eribo drum authorizes the swearing in of dignitaries, making all of us, the Efi and the Efó, one people. The Sése drum is our mother given to us by God [Abasí]). The chorus repeats, "Ekóbio Enyegueyé monína son ekóbios" (The members of the group Enyegueyé are our brothers). In referring to the ritual kinship of the Efí and Efó people of the Cross River Basin, and then to the white Abakuá group, these lyrics imply that in Cuba, all Abakuá members are "one people" and that race is not a obstacle to initiation. Underscoring the value of these Cuban ideals, "Criolla Carabali" contains the commonly used Abakuá term chébere. The chorus sings, "Efi Abarakó yeneka Mokóngo Machébere" (The group Efí Abarakó are valiant brothers). As the racial and class composition of the Abakuá became more inclusive, the society seemed to embody Cuban ideals of rebellion and self-determination within a creole society.

\section{Akabuá in Cuban Music}

\section{Ékue and Bongó}

Ékue, also called Bongó Ékue, is the single-headed friction drum sacred to Abakuá whose sound imitates a leopard roar. Ékue is revealed only to specific titled elders-it is heard, but not seen, by others. Ortiz wrote, "The Ekue is an instrumentum regni" (Ortiz 1955:236). Its "bull roarer" sound emerging from the famba temple is the signal that divine contact has been made, and that all other ceremonial activity may commence. Another Cuban drum is called bongó. It is a secular, double-headed drum of Kongo origin, and came to Havana with son music from Oriente Province in the early 1900 s. It apparently came with the name bongo ${ }^{24}$ - if so, the name is a marvelous coincidence, because there is no known historical relation 
between the secular bongó drum used in early Cuban son music and the divine Bongó Ékue. Bongó is rather a general term used throughout the Bantu territory, which extends up to Old Calabar. Still, the secular bongó can be manipulated to recreate both the roar of the Bongó Ékue as well as the rhythmic pulsations of the bonkó enchemiyá drum also used in Abakuá ceremony.

Several important secular bongó players and other musicians in early Havana son groups were Abakuá members. ${ }^{25}$ In the 1928 recording of "Dónde estás corazón," the Abakuá member Agustin Gutiérrez of Sexteto Habanero simulates (using a technique called "glissade") the roar of Ékue on his bongó (Sexteto Habanero 1995b). In a 1928 recording under the direction of Abakuá member Ignacio Piñeiro (1888-1969), bongócero José Manuel Incharte "El Chino" clearly imitates the roar of the Ekue fundamento (Sexteto Nacional 1993).

In his classic mambo "Bábarabatíri" Beny Moré makes a coded reference to Abakuá by shouting "Ikui!," a variation of "Ékue" (Moré 1950). He performs a similar gloss, "Ekue irikue," at the end of "En el tiempo de la colonia" (Moré 1982a). In another mambo, Machito and His Orchestra make coded references to the Abakuá Society by singing "Yo soy asarori/ Rumba, para los Abase ao." In Abakuá, asarori means good or fine; "los Abase" refers to Abakuá neophytes, or "the children of Abasí" (Machito 1993). 26 This is not "cross-over music," that is, music intentionally whitewashed and primly dressed for mass consumption. This music serves a dual purpose: to reach an international dancing public, and to communicate in codes with those Cubans whose sentiments are attuned to African-derived religions. This "double performance" phenomenon is known to occur throughout Caribbean culture, not only in music but also in political discourse, literature, and art (Benítez-Rojo 1992:220-21). ${ }^{27}$

Other practicing Abakuá of the period often presented their material in coded forms deliberately intelligible only to those in the know. In the 1920s Ignacio Piñeiro composed "En la alta sociedad" (In high society) which begins with a burlesque of high society people attempting to play Abakuá rhythms (Vera 1994). ${ }^{28}$ The song ends with a call-and-response chant led by the Moruá Yuánsa (The singing dignitary): "Ekue Uyo Ke Akanapon dibio dibio dibio kondo" (The voice of our sacred mother Ékue is roaring). The response is a long phrase that mentions three important dignitaries (Mosóngo, Efí Méreme, and Ekueñón) and a phrase from the tratado (mythic history) of one of the oldest and most powerful Abakuá groups at the time, Abakuá Efó of Regla: "Sanga prokama nandibá ekóbio Abakuá Efó" (I am going to the sacred river, my brothers). This song was one of many in a genre created by Piñiero called "clave ñaniga" using the Abakuá standard 6/8 meter and complete Abakuá phrases (hablando en 'lengua') (Linares 1998).

Despite the coded language, Abakuá members who have performed song or theater that re-enact ceremonial procedure have faced suspension 
or removal from within the society for having revealed its secrets and intimate language before a secular audience (Ortiz 1981:444,446). Several Abakuá elders told me that Piñeiro was barred from becoming a dignitary of his Abakuá group. ${ }^{29}$ In fact, Abakuá music and chants can be recorded commercially without revealing secrets, because few outside the society understand the language. In like fashion, Yorùbá diviners of West Africa (called babaláwo) speak an esoteric language and thus they can converse with each other about secrets in public (Abímbọ́lá 1998). Even so, the Abakuá group to which Piñeiro belonged, the oldest in Cuba, seems not to have permitted the public performance of Abakuá language.

Piñeiro not only recorded Abakuá chants commercially but also wrote lyrics about a little known aspect of the brotherhood: the white males of elite society who became Abakuá members from the 1860 s onward. Juan de la Cruz Iznaga, a founding member of the Septeto Nacional and an Abakuá, had many contacts among Cuban businessmen and politicians. ${ }^{30}$ Piñeiro's "Iyamba bero" (ca.1925-28) refers to the local politicians and businessmen he met in the course of playing music for their private parties.

Lucky Havana / that confounds people, / the worst one is decent / and lives the easy life, / whom you least suspect / is a pure Abakuá / who takes off his suit / and plays the bonkó / and calling the Iyámba Beró / intones sonorously / like a regal Obonékue / a harmonious rhythm. (Chorus): Yayo banankéme / Efóri Nkomón komon banankéme. ${ }^{31}$

The lyrics indicate that appearances can be deceiving in Havana, where upper-class "whites" sometimes participate in "black" working-class traditions. Piñeiro specifically refers to the dual life styles of wealthy white Abakuá members who wear suits during the day and yet participate in ceremonies (commonly in bare feet) on the sly. The chorus mentions the name of Piñeiro's group, Efóri Nkomón, the oldest in Cuba (founded in 1840). Fernando Ortiz (1954:69-71) and Lydia Cabrera also wrote about the not uncommon phenomenon of white Cubans from the elite who participate in Afro-Cuban religions (Miller 1995; Miller forthcoming). This points once more to the symbolic importance of Abakua in Cuba, in that it extends beyond categories of race and class to the idea of nation. Men participate because in doing so, they become more creole in a particularly Guban way.

\section{Rumba}

Ritual Abakuá music and dance, as performed both by Abakuá and by nonAbakuá, have influenced a variety of secular Cuban music and dance forms. The use of the Abakuá term for sweet music with a groove-ibiono-in the guaguancó (a genre of rumba music) signals the influence of Calabar in the street music of Havana and Matanzas. In December 1997 I watched a street 


\section{African Studies Review}

rumba organized and performed by the Abakuá group Amiabón Brandy Masóngo in the Colón barrio. ${ }^{32}$ Contemporary rumba/"folkloric" groups like Los Muñequitos de Matanzas and Grupo AfroCuba (many of whose members are Abakuá) play Abakuá ceremonial music as standards, along with all genres of rumba (yambú, guaguancó, and columbia). ${ }^{33}$ During a recent baróko (ceremony) of the group Obón Séne Efó, Jacinto Scull "Chori" (Enkóboro of the group Irianabón Brandí Masóngo and founder of the rumba group Yoruba Andábo) took me to one side of the patio and, utilizing the typical ekón (bell) pattern of the Abakuá music (as heard, for example, on Yoruba Andabo 1993 or Conjunto Folklórico 1964), sang various classic texts of the columbia genre, including "Rumbero mayor" and "Ogun Awanile," demonstrating one more time the easy oscillation between Abakuá chants and the rumba. ${ }^{34}$

Many rumba performers and composers have been Abakuá. Because the original, street-styled rumba was marginalized and rarely recorded before the revolution, many of its early composers and even compositions remain obscure. ${ }^{35}$ We do know that Chano Pozo (1915-48), a member of the group Muñanga Efó, composed the now classic "Blen, blen, blen" in 1940 (Embale 1988). ${ }^{36}$ Through a conversation with Horacio L'Lastra, the Mokóngo of the Abakuá group Endibó Efó, I learned that he composed the guaguancó "Pongan Atención," recorded by Beny Moré in 1957 (Moré 1994; L'Lastra 1996). Using an Abakuá title, Justi Barreto (1923-) of the group Usagaré Mutánga composed "Batanga No. 2" (Moré 1982b), whose lyrics refer to Kongo and Arará (Dahomey) practices (Cabrera 1988:102). Because compositions like "Batanga No. 2" contain diverse cultural elements, they are "super-syncretic." In such rumbas, polyrhythms are powerful vehicles that facilitate this integration, and Abakuá is one of its vital sources.

\section{Abakuá Influence as a Global Phenomenon}

\section{Abakuá in Africa}

Cuban popular music, now performed throughout the Americas, Asia, Europe, and Africa, became wildly popular throughout sub-Saharan Africa from the late 1940s onward..$^{37}$ A major factor was the "GV" series of the British EMI record company, which exported over two hundred titles of mostly Cuban music (Stapleton \& May 1990:20). In addition, African elites returning home from Paris brought Cuban recordings with them. AfroCuban-styled dance bands, formed from Senegal to Kenya to the Republic of the Congo, often sang in Spanish (Harrev 1992; Kazadi 1971). In this context many Africans who became musicians remember listening to Cuban rumba and son as children. One of them, Ricardo Lemvo, originally from Kinshasa, Republic of Congo, recently recorded "Mambo Yo Yo," an inter- 
national hit based on Afro-Cuban linguistic and rhythmic traditions. It includes the Abakuá phrase, "Endeme Efí enyeneká okóbio, ekóbio barorí asomañongo Abasi" (The Ireme that appeared at the consecration of the Efó and the Efí came from the divine forest) (Lemvo \& Loca 1998). ${ }^{38}$ As in "Criolla Carabalí," the lyrics celebrate the unity of the Efi and Efó through their membership in the society, underscoring the value of multiethnic solidarity.

Why has this music become so influential in Africa? Aside from being conducive to vibrant singing, partner dancing, and other forms of aesthetic pleasure, its African and Afro-Guban rhythms, instruments, and language represent a political ideology that nurtures indigenous local cultures. This was significant to African musicians who had gained new awareness of their own heritage during national independence movements (Stapleton \& May 1990:20). In the global arena, the creole, therefore multiracial and inclusive, identity embodied by this music has made it significant to those who reject "ethnic purity" in music as well as in other cultural forms.

\section{Afro-Cuban Cabaret Music and Jazz}

Since the early twentieth century, Cuban music has reached other international audiences in at least three ways: through early recordings by RCA Victor and Columbia records in Havana, New York, and Spain; through American and European tours of Cuban orchestras like the Lecuona Cuban Boys; and through fusion with United States jazz. Some composers of cabaret-style music have juxtaposed words from Lukumí, Palo Monte, and Abakuá liturgies for their exotic appeal on the international market. With the concurrent interest in black culture in Paris and New York that nourished "Negritude," the Harlem Renaissance, as well as the related Afrocubanismo movement of Havana, groups like the Lecuona Cuban Boys (who were probably not Abakuá) toured successfully with their cabaretstyle music. Even if they did not really know the meaning of the words they sang, no one in the audience did either! These works are not valuable as sources for learning about the society in the way that Piñeiro's and the Sexteto Habanero's compositions are, but they do reflect the diffusion of AfroCuban music into a global phenomenon. In 1937 the Lecuona Cuban Boys recorded "Chevere," which includes the lyrics, "I am chévere ... the black man who never looks back is chévere" (Lecuona 1992). ${ }^{39}$. Through the popularity of the Cuban son and its derivative, Salsa music, the word chévere (or chébere) is now used throughout Latin America and recently in the United States. The contemporary Cuban singer Issac Delgado is known as "El chévere de la salsa" (Delgado 1994). In 1972, Stevie Wonder recorded a song that revolved around this Abakuá term. He sang, "I speak very very fluent Spanish, todo está bien chébere, you understand what I mean?, ¡chébere!" The chorus responded with "Don't You Worry 'Bout a Thing ¡chébere!" (Wonder 1972). "Folie Negre," recorded by The Lecuona 
Cuban Boys in 1936, uses other Abakuá and Kongo phrases (Lecuona 1993). It begins: "Yamba e, Yamba e [a reference to Iyámba, high dignitary] Eyeneka [from the society's name, Enyéne Abakuá] Owakaómba Nganga [Nganga: a Kongo phrase for fundamento] Ekoriko Abakuá [a gloss on the society's name, Ekório Enyéne Abakuá] Mokondo, Mokondon do [Mokondó: the costume of an Íreme dancer] Yamba e Mokóngo [ two Abakuá dignitaries] Efi Etete Mokóngo [Efí Etéte: an Abakuá group]. ${ }^{40}$ The song ends with an imitation of the roar of the Ékue drum.

In Afro-Cuban jazz (or Latin jazz), among the first great milestones were two compositions by Dizzy Gillespie and the Cuban drummer Chano Pozo. Called "Manteca" and "Afro-Cuban Suite," they were performed in 1947 with the Gillespie Band, integrating Abakuá ceremonial music and chants with jazz harmonies. ${ }^{41}$ In "Afro-Cuban Suite," Pozo chants "Iyí baribá benkamá," a ritual phrase paying homage to the celestial bodies. Dizzy performed these compositions into the mid-1980s as standards, fusing Abakuá rhythms to U.S. popular music. ${ }^{42}$

The enduring legacy of this collaboration is felt in numerous ways. In the late 1940s conga and bongó drums became symbols for the emerging beatnik movement, and the conga drum is now a standard instrument in the United States. In Cuba, groups like Irakere have developed sophisticated jazz vocabularies. Musical tributes to Chano Pozo began in 1949, the year after his death (Valdés 1994), and continue to the date of this writing (Reyes 1999). In 1954, Perez Prado recorded "Voodoo Suite (Afro Cuban Jazz Suite)," which uses some Abakuá words (Unkeré boko unkénde; Mímba; Yamba-O) in call-and-response phrases based on Pozo's "Afro Cuban Suite." In 1977 in California, Cuban bassist "Cachao" recorded his composition "Ecué: Ritmos Cubanos," a jam session beginning with the Abakuá ekón (bell) pattern and reminiscent of Pozo's work (Bellson 1977). In 1977 in Havana, David Amram recorded "En memoria de Chano Pozo" with Los Papines (Amram 1978), a rumba group whose members are Abakuá (Miller forthcoming). In 1996, the Cuban drummer Tata Güines recorded a bold version of Beny Moré's "Rumberos de Ayer" (Rumba players of yesterday). This tribute to Chano Pozo begins with an Abakuá chant sung by "Goyo" Hernández (himself a member), "Chano Pozo Obonékue Efóri Muñánga Ékue ata upon mañón ata chiminakako mañóngo Chano Pozo Abasí menguáme" (Güines 1996). This phrase affirms Chano's status as Obonékue (initiate) of the Abakuá group Muñánga Efó, and ends with "Abasí menguáme"(May God bless you). After the chant, the music changes to a guaguancó rumba, a reaffirmation that modalities of Cuban sacred and popular music interweave at high velocities. In New York City, the legacy of the Dizzy/Chano collaboration runs powerfully through the music of Bobby Sanabria, a jazz drummer whose new album integrates Abakuá themes with, for example, Charlie Parkers's "Donna Lee," in the call-and-response chant "Chébere que chébere, chébere kiñóngo!" (Sanabria 2000). 


\section{Prognosis}

Abakuá, like other Afro-Cuban religions, is esoteric, non-proselytizing, and hidden from the general public. Yet musicians who have been Abakuá have used its themes and liturgical traditions to generate Cuban popular music from the late nineteenth century until today (the cha-cha-cha, the danza, the danzón, the mambo, the rumba, the son, the songo, the timba, and the trova). The Abakuá language, though considered secret, has continually been recorded in popular music. Because the society is hermetic, these recordings are an important source for scholars who seek to understand the impact of Africa in Cuba.

Don Fernando Ortiz (1881-1969) is regarded as the "third discoverer" of Cuba, largely for his pivotal and voluminous studies of Cuba's African influences. In 1913 he argued that "orthodox" African influence in Cuba would be "extinguished" as those born in Africa died out and their descendants became more and more Cubanized (1987:89). Anthropological theory of Ortiz's day held that so-called primitive religious cultures would become extinguished or assimilated as a result of contact with Western education and logic. A 1923 recording of an Abakuá musical theme seems to support Ortiz's claim. "Los cantares del Abakuá" by Piñeiro is performed in a "folk music" style (with guitar and two harmonizing voices) in both Spanish and Abakuá, an arrangement that suggests the dilution of Abakuá "orthodoxy" by mixing Spanish and Abakuá texts, ritual chants with a guitar duo (Vera 1998). In the 1920s Afro-Cuban music was somewhat marginalized-partially hidden and only recorded commercially within musical structures acceptable to the buying public. As African-derived culture was seen as a hindrance to the integration of blacks into Cuban society, its presence was diminished in recordings.

Why is it, then, that jazz in the U.S. has been recharged (i.e.,"reAfricanized") through Cuban ritual music instead of, say, the African-American Ring Shout that Sterling Stuckey argues laid the foundation for jazz music? (Stuckey 1987:95, 364 n.53). How is it possible that Abakuá has not only survived in Cuba, but also become vital to its popular culture? How is it possible that in the 1990s, "orthodox" Abakuá music as it is heard in secret ceremonies is being recorded completely in the Abakuá language?

Africans in Cuba did die out, but many of their descendants (as well as those of European and Asian ancestry) maintained variants of African ancestral religious traditions by hiding them from the larger society. These cultural traditions, moreover, gained exposure during the Cuban Revolution, as political leaders framed the rebellious nature of nineteenth-century anticolonial institutions like the Abakuá as important building blocks upon which the revolution triumphed. ${ }^{43}$ Today, the impact of the current economic crisis is evident in the tourist industry that has been created around Afro-Cuban religious culture. Within this unprecedented context, Abakuá (as well as Ocha and Palo Monte) ceremonial music is being commercially recorded. 
One result is that the influence of Afro-Cuban religions in popular culture has reached new dimensions, as professional rumba/folklore groups record albums and tour internationally. The National Folklore Ensemble, founded in 1962, has presented Afro-Cuban religious music and dance as a vital aspect of the national culture. Most of the original members of the rumba group Yoruba Andabo, founded in 1961 by stevedores from the wharves of Havana, were Abakuá members or their descendants. The lengthy Abakuá tratados in their 1993 recording indicate that the Abakuá have maintained their language orthodoxy and have not replaced it with Spanish vocabulary. This album contains "Enyenison Enkama" (Africa speaks), a performance of Abakuá music and tratados (exclusively in Abakuá ) related to the territories of Orú and Efó (Yoruba Andabo 1993). On the same album is "Protesta Carabalí," a rumba-styled history lesson that begins, "I'm going to delve deeply/ into the struggle of Cuba/ so you learn to respect it...." After mentioning that Carlos Manuel de Céspedes freed his own slaves in 1868, the track moves into Abakuá music and language, underlining the fact that Abakuá was established in Cuba to defend and liberate black slaves. ${ }^{44}$ Their 1997 recording of Abakuá music is the clearest commercial recording of Abakuá tratados to this date. The lead voice, after announcing "Iyibaribá benkamá," his intention to chant in the ceremonial way, begins:"Okobio Enyenisón, Awanabekura Mendo/ Núnkue Itia Ororo Kánde Efí Kebutón/ Oo Ékue" (Our African brothers in Awanabekura Mendo [Efó territory] came to Cuba, and in Regla founded Efi Kebutón" [the first group]). The extensive enkame (chant) then goes on to mention the very oldest Cuban Abakuá groups from Efi territory (Ekerewá Ikanfioró, Ápapa Efí Umoní) (Yoruba Andabo 1997).

Cuba's Ministry of Culture has officially recognized the value of earlier traditions to contemporary Cuban music. Around 1970 the Septeto Nacional de Ignacio Piñeiro (founded in 1927), which records Piñeiro's standards as well as new music, came under government protection as one of the "National Interests." ${ }^{45}$ Frank Oropesa, the bongó player for the group (and an Abakuá member), recently composed "Pon atención al Abakuá" (Pay attention to the Abakuá), a tribute to Piñeiro's clave ñañiga, which begins with short Spanish phrases and then launches into Abakuá enkames (chants) (Oropesa \& Blanco 1997). Cuba's most famous dance band, Los Van Van, has recently recorded the smash hit "Appapas del Calabar," named after the Africans who founded Abakuá in Cuba, with a refrain taken straight from a Abakuá processional chant to initiate a new members. As Cuban leaders continue to offer Cuban independence struggles as examples of a national revolutionary heritage, and as artists continue learning that there really is rich material in Afro-Guban artistic traditions, cultural workers will likely continue to use local historical genres and themes. The Abakuá, more and more heralded as a symbol of Cuba's uniqueness, will only rise in importance. As the refrain from "Appapas del Calabar" suggests, in helping to re-create Africa in Cuba,the Abakuá fun- 
damento has made Cuba a sacred land: Ékue, Ékue, chabiaka Mokóngo Ma' chébere!

\section{References}

Abímbộlá, Wán̄dé. 1998. Personal communication. Cambridge, Mass., December 12. Afigbo, Adiele. 1981. Ropes of Sand: Studies in Igbo History and Culture. Ibadan: Ibadan University Press.

Afro-Cuban All Stars. 1997. "Los Sitio' Asere." A toda Cuba le gusta. Nonesuch 794762.

Amram, David. 1978. "En memoria de Chano Pozo." David Amram: Havana/New York: The Historic U.S.-Cuban Musical Exchange of 1977. Flying Fish FF-057.

Arends, Jacques, Pieter Muysken, and Norval Smith, eds. 1994. Pidgins and Creoles: An Introduction. Amsterdam: John Benjamins.

Bascom, William R. 1980. Sixteen Cowries: Yoruba Divination from Africa to the New World. Bloomington: Indiana University Press.

Bellson, Louie. 1977. "Ecué." Composed by Israel López, "Cachao." Ecué: ritmos cubanos. California.

Benítez-Rojo, Antonio. 1992. The Repeating Island: The Caribbean and the Postrnodern Perspective. Translated by James E. Maraniss. Durham: Duke University Press.

. 1998."Música y nación: el rol de la música negra y mulata en la construcción de la nación cubana Moderna." Encuentro de la cultura cubana (Madrid) 8-9: 43-54.

Bentley, Rev. W. Holman. 1887. Dictionary and Grammar of the Kongo Language, as spoken at San Salvador, the Ancient Capital of the Old Kongo Empire, West Africa. London: Trübner \& Co.

Cabrera, Lydia. 1936. Contes Negrès de Cuba. Paris. (Published in Madrid in 1972 as Cuentos negreo de Cuba.)

. 1984. Vocabulario congo (El bantú que se habla en Cuba). Miami: Colección del Chicherekú en el exilio.

. 1988. La lengua sagrada de los Ñáñigos. Miami: Colección del Chicherekú en el exilio.

Caignet, Félix B. 1993. "Carabalí.” Recorded by Ronda Lirica Oriental in 1928. Hot Music From Cuba, 1907-1936. HQ CD 23.

Campbell, Horace. 1987. Rasta and Resistance: From Marcus Garvey to Walter Rodney. Trenton, N. J.: Africa World Press.

Carpentier, Alejo. [1933] 1979. „Ecue-Yamba-O! Madrid. [1946]1980. La música en Cuba. 2d ed. Mexico: Fondo de Cultura Economica.

Caturla, Alejandro García, and Alejo Carpentier. 1980. "Poemas afrocubanos," "Elegia del enkiko." In Música vocal. Havana: Editora Musical de Cuba.

Conjuntc. Céspedes. 1995. "Ibiano." Composed by Elio Revé. Vivito y coleando. Xeno 4033.

Conjunto Folklorico Nacional de Cuba. 1964. "Enkame." Havana, Areito. LDA 3156.

Crabb, David W. 1965. Ekoid Bantu Languages of Ogoja, Eastern Nigeria. Part 1: Introduction, Phonology and Comparative Vocabulary. West African Language Monographs 4. Cambridge: Cambridge University Press.

Delgado, Issac, and Adalberto Alvarez. 1994. El chévere de la salsa - El caballero del son. CD 35749-2. BMG Music. 
Deschamps Chapeaux, Pedro. 1964. "Margarito Blanco 'Osongo de Ultán.'” Boletin del Instituto de Historia y del Archivo Nacional 65: 97-109.

. El negro en la economia habanera del siglo 19. Havana: UNEAC.

Díaz Ayala, Cristóbal. 1994. Cuba canta y baila: Discografía de la música cubana. Primer volumen: 1898-1925. San Juan: Fundación Musicalia. $.1999 \mathrm{a}$. Letter to the author. June 6 . 1999 b. Letter to the author. July 8. 1999c. Letter to the author. August 9.

Dizzy Gillespie: Complete RCA Victor Recordings. 1995. RCA CD 66528-2.

Dizzy Gillespie y Arturo Sandoval en vivo. 1985. "Swing Love." Festival Latino Plaza. EGREM LD 4271.

Dizzy Gillespie/Max Roach in Paris. "Afro-Guban Suite." BMG Music. GD 0902668213-2.

"E1 Ñáñigo." 1982. The Cuban Danzon: Its Ancestors and Descendants. Ethnic Folkways Records FE 4066.

Embale, Carlos. 1988. "Blen, blen, blen." Written by Chano Pozo, 1940. Todavia me queda voz. EGREM.

. 1995. "En el tiempo de la colonia." Written by Mario Recio. Que bonito canta. CD 0102 EGREM.

Febles, Juan "Juanillo." 1996. Audio recorded conversations in Havana, December.

Faraclas, Nicholas G. 1989. "Cross River." In John Bendo-Samuel, ed. The NigerCongo Languages. Lanham, Md.: University Press of America, 377-99.

Forde, Daryll, ed. 1956. Efik Traders of Old Calabar. London: International African Institute.

Gates, Henry L. 1988. The Signifying Monkey: A Theory of African-American Literary Criticism. New York: Oxford University Press.

Guillén, Nicolás. [1930] 1974. "Motivos de Son." In Nicolás Guillén: Obra poética, 1920-1958. 2d ed. Havana: UNEAC.

Güines, Tata. 1996. "Homenaje a Chano Pozo." Aniversario. EGREM, GD 0156, Havana.

Hall, Gwendolyn Midlo. 1992. Africans in Colonial Louisiana: The Development of AfroCreole Culture in the Eighteenth Century. Baton Rouge: Louisiana State University Press.

Harrev, Fleming. 1992. "Francophone West Africa and the Jali Experience." In West African Pop Roots, ed. John Collins. Philadelphia: Temple University Press, 209-43.

Hechavarria, Emilio. 1998. Conversation with author, barrio Cayo Hueso, Havana, May.

Henderson, R. 1972. The King in Every Man: Evolutionary Trends in Onitsha Ibo Society. New Haven: Yale University Press.

Hernández, Florencio "Carusito," and Juana Loisa Galano. 1998. Conversation with author, Havana, March 11.

Herrera, Lázaro. 1999. Audio recorded conversations, Havana, February, March, April, May.

Kazadi, Pierre. 1971. "Congo Music: Africa's Favorite Beat. A Kinshasa/Brazzaville Style Built on an Afro-American Synthesis." Africa Report 16, no. 4 (April): 25-27.

King, Chester. 1999. Conversation with author, Cambridge, Mass., May.

Lapique, Becali Zoila. 1979. Músiéca colonial cubana en las publicaciones periódicas (1812-1902). Vol. 1. Havana: Editorial Letras Cubanas. 
Lecuona Cuban Boys. 1992. Vol. 3, 1934-42. "Chevere." Recorded in Paris, 1937. Harlequin HQ CD 21.

1993. "Folie Negre." Written by Moisé Simons. Recorded in Paris, 1936. Emesto Lecuona and the Lecuona Cuban Boys, 1932-1936. Vol. 4. HQ CD 26.

Lemvo, Ricardo, and Makino Loca. 1998. "Mambo Yo Yo." Afro-Latino. Putumayo World Music, PUTU 139-2 CD.

León, Argeliers. 1991. "Of the Axis and the Hinge: Nationalism, Afro-Cubanism, and Music in Pre-Revolutionary Cuba." In Essays on Cuban Music: North American and Cuban Perspectives, ed. Peter Manuel. Lanham, Md.: University Press of America, 267-82.

Linares, Dra. María Teresa. 1996, 1998. Conversations with author, May, March.

L'Lastra, Horacio. 1996. Conversation with author, Guanabacoa, Havana, August.

Machito and His Orchestra, Featuring Mario Bauza. 1993. "U-Bla-Ba-Du." Written by Pepe Becke. Recorded 1948 or 1949, New York City. The Original Mambo Kings: An Introduction to Afro-Cubop. Verve CD 314513 876-2.

Manfredi, Victor. 1991. "Ágbọ̀ and Ẹ́hụgbò: İgbo Linguistic Consciousness, Its Origins and Limits." Ph.D diss., Harvard University.

Martínez-Alier, Verena. 1989. Marriage, Class and Colour in 19th Century Cuba: A Study of Racial Attitudes and Sexual Values in a Slave Society. Ann Arbor: University of Michigan Press.

Matibag, Eugenio. 1996. Afro-Cuban Religious Experience: Cultural Reflections in Narrative Gainesville: University Press of Florida.

Meek, C. K. 1937. Law and Authority in a Nigerian Tribe: A Study in Indirect Rule. New York: Oxford University Press.

Mendoza, Celeste. 1997. "Saoco." Written by Rosendo Ruiz. Recording date unknown. Cuba: I am Time. Blue Jackel CD 5012-2.

Miller, Ivor. 1995. "Belief and Power in Contemporary Cuba." Ph.D. diss., Northwestern University.

Histories of the Abakuá Society: Narrated by Andrés Flores Casanova. Forthcoming.

Morales, Obdulio. 1937. "Enyoró." Recorded by the Augusto Coen orquesta. Decca Records.

Moré, Beny. 1950. "Bábarabatíri." Written by Antar Daly. . 1982a. "En el tiempo de la colonia." Written by Mario Recio. Recorded in August 1954. Sonero mayor. Vol. 4. EGREM, LD-3708.

. 1982b. "Batanga No. 2." Written by Jústiz Barreto before 1959. Sonero mayor. Vol. 8. EGREM, LD-4061.

1994. "Pongan Atención." Written by Horacio L'Lastra. The Very Best of Beny Moré and His All Star Afro-Cuban Big Bands. Vol. 2. Recorded October 2, 1957, Havana. Tropical/Classic CD-P.

Moore, Robin D. 1997. Nationalizing Blackness: Afrocubanismo and Artistic Revolution in Havana, 1920-1940. Pittsburgh: University of Pittsburgh Press.

O'Neil, Jack. 1999. Letter to the author. July 6.

Oropesa, Frank, and Pablo M. Blanco. 1997. "Pon atención al Abakuá" (sonAbakuá). Septeto Nacional Ignacio Piñeiro: Piñeiro se baila con son. Sonpat Sarl. Recorded in Cuba, CD SP 0005.

Orovio, Helio. 1992. Diccionario de la música cubana. 2d ed. Havana: Editorial Letras Cubanas.

Ortiz, Fernando. 1952. Los instrumentos de la música afrocubana. Vol. 2. Havana: Ministerio de Educación. 
1954. Los instrumentos de la música afrocubana. Vol. 4. Havana: Cárdenas y Cía.

1955. Los instrumentos de la música afrocubana. Vol. 5. Havana: Cárdenas y Cía.

1960. La antigua fiesta afrocubana del Día de Reyes. Havana: Ministerio de Relaciones Exteriores.

1981. Los bailes y el teatro de los negros en el folklore de Cuba. 2d ed. Havana: Letras Cubanas.

. [1913]1987. "Las supervivencias africanas en Cuba." In Entre cubanos: psicología tropical. 2d ed. La Habana: Editorial de ciencias sociales.

Paquette, Robert L. 1988. Sugar Is Made with Blood: The Conspiracy of La Escalera and the Conflict between Empires over Slavery in Cuba. Middletown, Conn: Wesleyan University Press.

Pascual Pons, Carmen. 1997. Acercamiento a las sociedades secretas Abakuá en Guanabacoa. Havana: Archivo del Museo de Guanabacoa.

Piñeiro, Ignacio. c1925-1928. "Iyamba bero" (clave ñáñiga). Performed by Cruz, Bienvenido y Villalón. $78 \mathrm{rpm}$. Columbia records \#2421-X (93950).

. 1995. "Guaguanco Callejero." Sung by "Goyo" Hernández. Rapsodia Rumbera. Recorded in Havana, 1995. EGREM CD 0121.

Prado, Perez. [1954] 1995. "Voodoo Suite (Afro Cuban Jazz Suite)." Prez: the Mambo King. Vol. 2. BMG 74321-31955-2.

Reyes, Jorge. 1999. Tributo a Chano Pozo. Recorded and mixed in Havana. BIS Music. CD-162.

Salazar, Max. 1993. "Chano Pozo: Part 1." Latin Beat 3.3 (April): 6-7.

Sanabria, Bobby. [1999] 2000. Afro-Cuban Dream: Live and In Clave. Bobby Sanabria Big Band. Arabesque GD AJO149.

Serviá, Estanislao. n.d. "Chevere Macumchevere." El Danzón. Orquesta Antonio Ma. Romeu, EGREM LD 3037.

Sexteto Habanero. [1928] 1995a. "Criolla Carabali." Written by Guillermo. Castillo. Sexteto Habanero 1926-1931, Harlequin HQ CD 53.

. [1928] 1995b. "Dónde estás corazón." Written by Martínez Serrano. Sexteto Habanero 1926-1931, Harlequin HQ GD 53.

Sexteto Nacional de Ignacio Piñeiro. [1928] 1993. "Mujeres enamorenme." Written by Bienvenido León. Hot Music From Cuba 1907-1936. HQ GD 23.

Sosa-Rodríguez, Enrique. 1982. Los Ñanigos. Havana: Ediciones Casa de las Américas.

Spottswood, Richard K. 1990. Ethnic Music on Records: A Discography of Ethnic Recordings Produced in the United States, 1893 to 1942. Vol. 4. Urbana: University of Illinois Press.

Stapleton, Chris, and Chris May. 1990. African Rock: The Pop Music of a Continent. New York: Dutton.

Stuckey, Sterling. 1987. Slave Culture: Nationalist Theory and the Foundations of Black America. New York: Oxford University Press.

Talbot, P. Amaury. 1912. In the Shadow of the Bush. London: William Heinemann.

Thomas, Hugh. 1997. The Slave Trade: The Story of the Atlantic Slave Trade: 1440-1870. New York: Simon \& Schuster.

Thompson, Robert Farris. 1984. Flash of the Spirit: African and Afro-American Art and Philosophy. New York: Vintage.

Trujillo y Monagas, D. José. 1882. Los criminales de Cuba y D. José Truijillo: narración de los servicios prestados en el cuerpo de policía de La Habana. Barcelona: Establec- 
imiento Tipográfico de Fidel Giro.

Urfé, Odilio. 1977. "La música y la danza en Cuba." In África en América Latina, ed. Manuel Moreno Fraginals. Paris: Unesco. 1992. Liner notes to Arcaño y sus maravillas, EGREM CD 0034.

Urua, E.nọ. 1997. "Object Movement in Eastern Lower-Gross." In Object Positions in Benue-Kwa, ed. Rose-Marie Déchaine and Victor Manfredi. The Hague: Holland Academic Graphics, 189-206.

Valdés, Miguelito. [1949] 1994. "Chano Pozo." (Mambo). Written by Vidal Bolado. Miguelito Valdés and His Super Orchestra: Mambo Dance Session. CG1050CD.

Van Van, Los. 1999. “Appapas del Calabar.” Llegó... Van Van. Havana caliente-Atlantic. 832227-2.

Vera, María Teresa. [1956] 1994. "En la alta sociedad." Veinte Años. GD 0056 EGREM.

. [1923] 1998. "Los cantares del Abacua." Written by Ignacio Piñeiro. Maria Teresa Vera y Rafael Zequeira: El legendario dúo de la trova cubana. Grabaciones históricas 1916-1924. Tumbao TCD 090.

Warner-Lewis, Maureen. 1996. Trinidad Yoruba: From Mother Tongue to Memory. Tuscaloosa: University of Alabama Press.

Waters, Anita M. 1985. Race, Class, and Political Symbols: Rastafari and Reggae in Jamaican Politics. New Brunswick, N. J.: Transaction Books.

Wifredo Lam and His Contemporaries, 1938-1952. 1992. New York: Studio Museum in Harlem.

Williamson, Kay, and Kiyoshi Shimizu, eds. 1968. Benue-Congo Comparative Word List. İbàdàn, Nigeria: University of İbàdàn.

, and A. O. Timitimi. 1983. Short Izon-English Dictionary. Port Harcourt, Nigeria: University of Port Harcourt Press.

Wonder, Stevie. 1972. "Don't You Worry 'Bout a Thing." Innervisions. Motown Records.

Yoruba, Andabo. 1993. "Enyenison enkama (Africa habla)." Yoruba Andabo: El callejón de los rumberos. Havana: PM Records.

1997. Del Yoruba al Son. La isla de la música. Vol. 6. Universal CD FMD 75141 .

\section{Notes}

1. The author thanks E. J. Alagoa, Jill Cutler, Cristóbal Díaz Ayala, Juan Febles, Radamés Giro, Jill Hartley, María Teresa Linares, Kathryne V. Lindberg, Victor Manfredi, Rogelio Martínez-Furé, Lynn Miller, Robin Moore, Colin Palmer, Armin Schwegler, and several Abakuá elders who wish to remain anonymous for their help toward the creation of this article. All translations are by the author unless otherwise noted.

2. Specifically the movement led by Aponte in 1812 and the Conspiracy of La Escalera in 1844 (Deschamps 1964:97-109). La Escalera (the Ladder) is thought by some historians to have been an international antislavery conspiracy. It was named after a ladderlike device to which Spanish and Cuban authorities tied suspected conspirators for torture and execution (Paquette 1988).

3. In the Abakuá Provincial Meeting on February 18, 1996, Esteban Lazo, the First Secretary of the Cuban Communist Party in Havana Province, said that there were fifteen thousand Abakuá members in Havana. (Pascual 1997:38, 40, 42). 


\section{African Studies Review}

4. To protect the Abakuá elders who granted me interviews, their names are not disclosed in this article.

5. Masonic groups like Roman de la Luz were in fact functioning in Havana contemporaneous with the Abakuá in the nineteenth century (Deschamps 1964:108). Men's secret societies are widespread across cultures of the world.

6. Fundamentos have deep significance not only for practitioners of Abakuá, but also for the Yorùbá-derived Ifá and Ocha religions, as well as for the Kongoderived Palo Monte practices, all of which have distinct fundamentos corresponding to their various divinities.

7. 'The words Ékue, 'leopard,' 'mother,' 'fish,' and others are homologous" (Ortiz 1954:38).

8. Ethiopia was originally used in the biblical sense (Psalms 68: 31), but came to mean the modern nation-state, as well as Africa in general (Campbell 1987:47-50, 220-224; Waters 1985:46-47).

9. This pattern of independent settlement closely resembles the social organization of precolonial southeastern Nigeria (Henderson 1972).

10. On June 29, 1998, I participated as the group Usagaré Ibondá Efó initiated the plaza of Moní Bonkó in the temple of the group Usagaré Ororó Mayambeke in Havana.

11. The Abakuá language appears to have been created in Cuba by integrating the lexicons and possibly syntaxes of several languages of Southeastern Nigeria and Southern Cameroon. In Cuba these languages are known as Kalabarí, Ápapa, Suáma, Orú, Bibí, Bríkamo, and Ósoso. In Africa, Kalaḅari is a dialect of Eastern Ijaw ( $(\mathrm{Ij}$ jo), a language cluster with several groups of dialects which have a "partial overlapping of intelligibility" between them (Williamson \& Timitimi 1983:xv,xvi). Ápapa is probably Àbàkpà, an Ėfik term for the Ejagham people (Forde 1956:66 note 1a). Ejagham are considered part of the Ekoi language cluster from the upper Cross River basin (Crabb 1965). Suáma derives from İsú-Amá, an ethnic term for an İgbo subgroup. İsú is a clan of the İgbo people, Amá means "of the road," i.e., "İsú Diaspora" (Afigbo 1981:12-13). Orú is a language known as Oro (Oron) in the Cross River. Faraclas classifies Oro (Oron) as a "Lower Cross Language" (1989: 384). Bibí is İbìbìo, an ethnic and linguistic term. İbìbìo languages have approximately two million speakers (Faraclas 1989:384). Oro, İbìbiò, Ėfik, and Usakade, all of which are important in Cuban Abakuá, are considered to be part of the same "Lower-Cross" language cluster, which have an estimated six million speakers (Urua 1997:189). Other groups known among Guban Abakuá as Efí, Usagaré and Efó are called Èfik, Usakade, and Efut in Africa (Ortiz 1954:35; 1955:242; Thompson 1984:241; Faraclas 1989:385).

12. Cabrera recorded this variation of the same phrase: "Mutiá kereké sanga molopó: oreja no puede pasar cabeza" (1988:370).

13. For a comprehensive overview of the Abakuá and other Afro-Cuban religions in literary treatment, see Matibag (1996).

14. "La rebambaramba," a ballet based on collaborations with Carpentier, was inspired by a nineteenth-century painting of the Día de Reyes celebrations, which presents the successive procession of three comparsas (carnival troupes), one Lukumí, the next Kongo, and the last Abakuá (Moore 1997:204; BenítezRojo 1998). 
15. An 1846 census claimed that there were 298 "white" and 618 "free colored" musicians in Cuba. From "Cuadro estadístico de la siempre fiel Isla de Cuba, correspondiente al año de 1846." Cited in Martínez-Alier (1989:169).

16. Sr. Febles, whose father was the babaláwo (Ifá diviner) Ramón Febles, and whose brother Ramón was a member of the Abakuá group Efóri Búman, can be heard playing güiro on the album Charanga: Nacional de Concierto, centenario del danzón, 1879-1979, EGREM, LD 3715.

17. A recording of "El Ñáñigo" (1982) by an orquesta típica composed of two clarinets, a cornet, a trombon, a figle (ophicleide), and two violins uses the same instrumentation as did Enrique Peña. According to Sr. Febles, an unreleased recording by the Orquesta Típica o de Viento (Benildes Morales Olivera, director) also using the same instrumentation as Peña, interpreted it closer to the militaristic conception of Peña's original. Performed for local radio, it is found in the archives of Odilio Urfé in 17 street and E street, Havana. "Juanillo" Febles played with this orchestra; I heard this recording from his personal archives.

18. Based on an interview with Cuban musicologist Lapique Becali in 1993, Robin Moore writes, "Although abakuá traditions do not seem to have affected the danzón musically or choreographically, it is likely that Fanlde and many of the musicians in his orchestra were members of such brotherhoods" (Moore 1997:24). Although Abakuá came to Matanzas circa 1862 (Miller forthcoming), and Faílde lived in a barrio with Abakuá traditions, more fieldwork is needed to confirm his membership. With greater certainty, I can say that Faílde was an initiate of Santería, and had Oyá (goddess of wind and transformation) "made." (Personal communication, May 1999, with Rogelio Martínez Furé, founder and artistic director of the Conjunto Folklórico Nacional de Cuba, whose grandmother lived in the same barrio as Faílde, and who was also an initiate).

19. Composer and flutist Octavio "Tata" Alfonso (1866-1960) blended elements of Abakuá liturgy into his danzones (Urfé 1977:234-35). Ricardo Reverón composed "Ireme Maco Ireme" (Urfé 1992).

20. "En el tiempo de la colonia, tiempo de Sese eribó" (Moré 1982). Recorded in 1954. Note that "Sese eribó" may be pronounced "Senseribó" on this recording. Although language pronunciation fluctuates, especially when sung, for the sake of clarity I have given the orthodox spelling.

21. Kiñongo literally means "sworn in, according to one of my anonymous informants. This composition also makes reference to Lukumí and Kongo religions. Carlos Embale was not Abakuá, but an initiate of Changó in the Lukumí tradition. Many of his family are Abakuá (Miller forthcoming).

22. Arsenio Rodríguez, "Yo soy Carabali, negro de nación ... . sin la libertad no puedo vivir." From his composition "Bruca Manigua" (son Afro-Cubano).

23. This legend is maintained on both sides of the Atlantic. Referring to general opinion of would-be slave-buyers about Cross River slaves in the seventeenth and eighteenth centuries, Hugh Thomas writes: "The slaves of Calabar were considered the least satisfactory, since they were rebellious" (1997:362).

24. This is the position of both Cuban musicologists and musicians I spoke with (Linares 1996). "Carusito" Florencio Hernández (1913-), a son musician since the $1920 \mathrm{~s}$, told me the double-headed drum was always called "bongó." His wife, Juana Loisa Galano, who was raised in Bayamo, Oriente, in the 1920s, 
remembers listening to musicians who played the "bongos" (Hernández \& Galano 1998). Although it seems unlikely, Fernando Ortiz thought that the secular bongó was named after the Bongó Ékue. He wrote, "The profane bongó drum ... carries this name taken from the original sacred bongó, or ékue...." (Ortiz 1955:242). Three interrelated terms for drum found in Cuba seem to demonstrate the use of general terms for drums throughout the Calabar/ Bantu region. Bongó is Efut for drum (Cabrera 1988:117); Bonkó is Èfik for drum (Cabrera 1988:125); Bongw, a Bantu term for "cavity," could also refer to a drum, specifically the Cuban bongó/bonkó (Sosa 1984:412); Ngoma is Kikongo for drum (Bentley 1887:373; Gabrera 1984:149).

25. Gerardo Martínez, lead voice and clave of the Sexteto Habanero (from the barrio of Belén) was Abakuá; Antonio Bacallao, botija (jug player) of the Sexteto Habanero (from the barrio Cayo Hueso) was a member of the group Ápapa Umoni Efí; Oscar Sotolongo, second bongocero (bongó player) of the Sexteto Habanero (from the barrio Cayo Hueso) was a member of the group Ápapa Umoni Efí; Agustín Gutierrez, third bongocero of the Septeto Nacional, was a member of Efóri Enkomón; Mario Carballo, bongocero of the Septeto Nacional (after 1971), was member of Munandibá Efó.

26 So, too, rumbera Celeste Mendoza sings, "Saoco en la tumbadora, asarorí en el omele" to show her delight at Sacoco's drumming skills (tumbadora and omele are two Afro-Cuban drums) (Mendoza, 1997). According to Jack O'Neil of Blue Jackel records, who searched the Guban archives, the dates of many recording sessions made in Havana, such as this one, are unknown, and do not appear on the original masters. He reported to me that "anything recorded before 1960 has no date, period. If there were dates on the recordings the Cuban government would not own the rights. The recordings were owned by other companies and became part of the state when the Revolution happened" (O’Neil 1999). Agreeing with O'Neil, Cristóbal Díaz wrote: "Cuba nationalized its record industry between 1960 and 1961. As a tactic, it appears, they do not want to give out recording dates made before and after the nationalization. I suppose that they are not sure that their confiscations were valid under International Rights and do not want to facilitate the proof of those who come to reclaim recordings made before the Revolution" (Díaz 1999c).

Performing Abakuá words in the context of nonsense syllables, as Machito's group did here, is a wonderful example of African American "Signifyin(g)." A former slave who became an abolitionist leader, Frederick Douglass wrote in 1845, "[the slaves] would sing, as a chorus, to words which to many seems unmeaning jargon, but which, nevertheless, were full of meaning to themselves" (cited in Gates 1988:66). As the slaves performed what was "unmeaning jargon" to standard English speakers, they were defining themselves in coded language. Techniques of "Signifyin(g)," allow blacks and other marginal speakers to communicate publicly in codes unknown to those who represent societal power.

27. One could also cite Bakhtin's "double-voiced word," James G. Scott's "hidden transcripts," Henry Louis Gates Jr.'s "Signifyin (g)" to describe the dual or even multivalent implications of this performance style.

28. María Teresa Vera may have performed this song as early as 1926, when Piñeiro played bass in her group, Sexteto Occidente.

29. Piñeiro was slated to be Enkríkamo of the group Efóri Enkomón, but was later 
barred. Emilio Hechavarria, adopted grandson of Ignacio Piñiero and trumpet player, confirmed this story to me. He learned it not from his family, but from elder musicians who knew his grandfather (Hechavarria 1998).

30. Juan de la Cruz Iznaga, according to an Abakuá elder I interviewed, was an obonékue (initiate) of the Abakuá group Abarakó Nankábia. In 1923 he recorded "Marcha carabalí," of the clave ñánigo genre, with the Trío Villalón (Díaz 1994:272). This composition, written by Piñeiro, was recorded twice more by de la Cruz in 1925, signaling its importance in the repertoire. (Spottswood 1990:1820-21).

31. "Dichosa Habana / Que confunde a la gente / el mas malo es decente / y vive a la campana / el que menos Ud. piense / es un puro Abakuá / que suelta la levita / y toca el bonkó / y llamando al Iyámba Beró / entona sonoro / como regio Obanékue / un armónio compás. [Chorus]: Ya yo banankéme / Efóri Nkomón komo banankéme."

My knowledge of this composition comes from interviews with Lázaro Herrera (1903-), trumpet player with Septeto Nacional for over fifty years and founder of that group (Herrera 1999). Recorded as "Iyamba bero" on a $78 \mathrm{rpm}$ (Piñeiro c.1925-28; Spottswọd 1990:1821), this song of the "clave ñaniga" genre survives in the repertoire of rumba groups in Havana. I heard Yoruba Andabo perform their version, "Oñó ñó ñó," in concert on April 24, 1999, in Havana. Another was recorded by "Goyo" Hernández (Piñeiro 1995).

32. The group sent out invitation cards that read, "De Amiabón Brandy Masongo, te invitamos a nuestra Rumba en el Barrio de Colon. Lugar: Blanco y Trocadero, 2:00 P.M."

33. Los Muñequitos, originally called Guaguancó Matancero, were founded in 1952 (Orovio says in 1956) (Orovio1992:305). Several founders were Abakuá, including Gregorio “Goyo" Díaz Alfonso (1929-96) of the Abakuá group Uriabón Efí Primero of Matanzas (a.k.a. Uriabón Kuna maribá) and Esteban "Chachá" Vega (1925-), the Moní Bonkó (ceremonial drummer) of the group Efî Enyumane of Matanzas (King 1999). Grupo AfroCuba de Matanzas was founded in 1957. Its current artistic director, Francisco Zamora Chirino "Minini," is a member of the group Uriabón Efi Primero of Matanzas.

34. The baróko took place in the temple of Muñanga Efó, San Miguel de Padrón, in 1998. "El Chori" passed away soon afterward on June 20, 1998.

35. The first recordings of street rumba known to me were made in the early 1950 s by Guaguancó Matancero on the Puchito label, and by the Conjunto de Alberto Zayas on the Panart label.

36. The first recording of "Blen, blen, blen" was made by the Casino de la Playa orquesta, sung by Miguelito Valdés, in January 1940, Havana (Díaz 1999b).

37. About Cuban rumba in Japan, see Shuhei Hokosawa, "Rumba in Japan in the 1930s," paper presented at the annual meeting of the International Association for the Study of Popular Music in Havana, Guba, October 13-20, 1994; cited in Moore 1997:181. Machito and other Cuban styled orchestras have consistently brought Afro-Cuban music to Japan since the rumba craze of the 1930s. The contemporary Orquesta de la Luz continues to present Cuban popular music in Japan.

38. From Cabrera (1988:331,387): "Mañongo: monte" (forest/bush); "Ndeme Efía ayereká okobio: Ireme que se manifesto en la consagración de Efor y de Efik (era el espíritu de Sikán)" (an Ireme who appeared at the consecration of Efor 


\section{African Studies Review}

and of Efik [it was the spirit of Sikán]). In addition, barori: good; Abasí divine. Mañongo, said one of my Abakuá informants, could also be fundamento, a supernatural extension of the powers of the forest.

39. "Yo soy chevere... el negro que no vira para 'tras jamas, es chevere" (Lecuona 1992).

40. The words as sung are "Efi tere," but they refer to "Efí Etete," the name of an Abakuá group.

41. In 1930 the Cuban Justo "Don" Azpiazu and his orchestra performed in New York City, where one of his musicians, Mario Bauzá, stayed. Afro-Cuban Jazz began in 1943 when Mario Bauzá, in the band Machito and His Afro-Cubans, composed "Tanga," yet Chano Pozo's "Manteca" brought the musical fusion to worldwide attention (Salazar 1993:6-7). (Afro-Guban Jazz was the term preferred by Mario Bauzá, considered the creator of the genre.)

42. Hear the original "Manteca" with Chano Pozo on Dizzy (1995). The best recording of Dizzy and Chano that I know of was "Afro-Cuban Suite," made live in Paris, 1948 (Dizzy/Roach:1995). Gillespie chanted Abakuá phrases he learned from Pozo into the 1980s in his composition "Swing Low" (Dizzy 1985).

43. In his July 26, 1974, speech, Fidel Castro referred to slave rebellions in the 1840 s in Matanzas by saying, "This was a heroic and beautiful page in the history of our country, ... and we could say that these men were precursors to our social revolutions." This was written on the wall of the museum of the Triunvirato sugar mill, in Cidra Matanzas, which I visited in January 2000.

44. "My voy a profundizar/ en la lucha de Cuba/ para que la aprendas respetar... Manuel de Céspedes los esclavos liberó / ese hecho ¿cómo se llama? / Ese hecho se llamó el grito de Yara / Asukumú kuán tiyén." "Protesta Carabalí" (Yoruba Andabo 1993). "Asukurú kuán tiyén" translates as "All powerful" (Cabrera 1988:81).

45. At the time the Cuban Ministry of Culture authorized several groups of "traditional music" (including the Septeto National, Septeto Habanero, Siglo 20, Septeto Típico de Sones, Tanda de Guaracheros) to function under the condition of being protected for "National Interests." Their aim was to "preserve the values" of Cuban traditional music. (Ignacio E. Aymé Castro "Richard," director of the Septeto Nacional, conversation with the author, November 21, 1999, Havana.) 